\title{
An Examination of Science High School Students' Motivation towards Learning Biology and Their Attitude towards Biology Lessons
}

\author{
Mustafa Kışoğlu ${ }^{1}$ \\ ${ }^{1}$ Faculty of Education, Aksaray University, Turkey \\ Correspondence: Mustafa Kışoğlu, Department of Science Education, Faculty of Education, Aksaray University, \\ Aksaray, Turkey
}

Received: January 9, 2018

Accepted: January 31, 2018

Online Published: February 3, 2018

doi:10.5430/ijhe.v7n1p151

URL: https://doi.org/10.5430/ijhe.v7n1p151

\begin{abstract}
The purpose of this study is to examine motivation of science high school students towards learning biology and their attitude towards biology lessons. The sample of the study consists of 564 high school students (308 females, 256 males) studying at two science high schools in Aksaray, Turkey. In the study, the relational scanning method, which is a descriptive scanning model, was utilized, with data obtained using the "Academic Motivation Scale for Learning Biology", consisting of four subdimensions (intrinsic motivation, amotivation, extrinsic motivation-career and extrinsic motivation-social) and 19 items, and the "Biology Science and Course Attitude Scale", consisting of three subdimensions (interest, pleasure and anxiety) and 23 items. Data were interpreted in accordance with arithmetic mean, percentage, frequency and significance levels. The significance level was taken as 0.05 . As a result of the research, the arithmetic means of students' intrinsic motivation and extrinsic motivation-career subdimensions were found to be above the scale mean. Students' mean score in the amotivation and extrinsic motivation-social subdimensions were below the scale mean. However, in each of the subdimensions on the attitude scale, students' arithmetic means were average. The highest relation among the subdimensions of the motivation and attitude scales was found to be between the intrinsic motivation and interest subdimensions and the intrinsic motivation and pleasure subdimensions. Nevertheless, as a result of the evaluation conducted in terms of students' gender and class level, it was determined that there was a significant difference between their gender and class levels in the subdimensions of motivation and attitude scales.
\end{abstract}

Keywords: Biology, Motivation for learning biology, Attitude towards biology lessons, High school students, Turkey

\section{Introduction}

\subsection{Significance of the Study}

So far, this century has been a period in which we have witnessed an increase in the importance of biology, along with the other science branches, as well as an increase in research regarding biology (Temelli \& Kurt, 2010). In addition to this advance in biology, importance given to biology and teaching biology has steadily increased (Yeşilyurt \& Gül, 2009; Sadi, Uyar \& Yalçın, 2014). Yet, biology lessons, which have relevance to daily life, are seen as a difficult by students (Staeck, 1995; McKee, 2002; Gül \& Yeşilyurt, 2010). Water transportation in plants and genetics (Bahar, Johnstone \& Hansell, 1999), along with hormones, genes, chromosomes, the processes of mitosis and meiosis, the neural system and Mendel genetics (Tekkaya, Özkan \& Sungur, 2001), are among topics that students have difficulty in learning about. According to Çimer (2012), one of the reasons why students find biology difficult is their negative attitude towards biology. Besides, motivation towards learning biology is one of the factors that influences students' achievements in biology as a subject (Aluçdibi \& Ekici, 2012a).

\subsection{Attitude}

Although there is no agreement on the concept or description of an attitude towards science, attitude is generally used to describe emotional tendencies towards events, people, place, situation and ideas (Simpson \& Oliver, 1990, as cited in Nasr \& Soltani K, 2011, p. 100). For instance, expressions such as "I love science", "I like science" or "science is boring" are taken as being representative of students' attitude towards science (Papanastasiou, 2002). Students' attitude towards science significantly affects their success in science (Prokop, Tuncer \& Chudá, 2007). Research shows that there is a relationship between the attitude towards science and being successful at science, with 
students displaying a highly positive attitude towards science enjoying greater success in this field (Alkan, 2006; Akpınar, Yıldız, Tatar \& Ergin, 2009; Fidan Dişikitli, 2011; Afari, 2015; Ali, Iqbal \& Akhtar, 2015). After analyzing TIMMS examination results from 2011, Martin, Mullis, Foy \& Stanco (2012) found a positive relationship between students' attitude towards science and their success in science.

\subsection{Motivation}

Another factor affecting students' learning and success is motivation (Uyulgan \& Akkuzu, 2014). Motivation involves complex psychological patterns used to explain efforts and behavior displayed in the course of different activities (Watters \& Ginns, 2000, p. 302). When considered in a learning environment, motivation is a concept that refers to students' expenditure of time and effort to fulfill the duties expected of them, as well as their willingness to use their skills for this purpose (Ergün, 2003). Deci \& Ryan (1985 and 1991, as cited in Aydin, Yerdelen, Gürbüzoğlu Yalmanc1 \& Göksu, 2014, p. 425) classified motivation as follows: intrinsic motivation, extrinsic motivation and amotivation. Intrinsic motivation, regarded as more important in education since it results in effective learning and creativity, is where a person displays a behavior because of internal emotions, such as pleasure and interest, while extrinsic motivation is where a person displays a behavior because of its results (Ryan \& Deci, 2000). Internal emotions, such as curiosity, interest, learning needs, competence and development sense, can be given as examples of intrinsic motivation resources; meanwhile, rewards, punishment, appreciation, pressure, requests, being liked (popularity) and approval can be regarded as examples of behavior caused by extrinsic motivation (Ergün, 2003). Amotivation means there is no intention in displaying the behavior. When the person is amotivated, she/he does not display the behavior voluntarily, and there is no reason behind the behavior being displayed (Ryan \& Deci, 2000). Amotivation is generally seen when the person receives negative reactions to repetitive failures and she/he does not feel capable of producing the desired results (Deci \& Ryan, 1985, as cited in Aydın, Yerdelen, Gürbüzoğlu Yalmancı \& Göksu, 2014, p. 426). Motivation plays an extensively important role in students' conceptual change development, critical thinking, usage of learning strategies and success in science (Tuan, Chin \& Shieh, 2005). Research exploring the relationship between students' success in science and their motivation towards science also shows that there is a relationship between motivation and science success (Bryan, Glynn \& Kittleson, 2011; Yenice, Saydam \& Telli, 2012; Chow \& Yong, 2013).

\subsection{Effect of Variables on Attitude and Motivation}

Studies in this area reveal that attitude and motivation can be affected by factors such as teachers' qualifications (Korur \& Eryılmaz, 2002; Korur, 2008; Elmas, 2013), teaching methods and techniques utilized during the lesson (Moralar, 2012; Kardaş \& Uca, 2016; Magwilang, 2016; Uzezi \& Jonah, 2017). Nonetheless, studies also show that some independent variables, except for factors that cause intrinsic motivation, extrinsic motivation and amotivation, such as gender (Craker, 2006; Spittle, Jackson \& Casey, 2009; Hegarty, 2010; Gömleksiz \& Serhatlığlu, 2013; Kumari \& Saraladevi, 2014; Jebson \& Hena, 2015; Yıldırım, 2017), age (Altun \& Yazıc1, 2010; Kaya \& Böyük, 2011), class level (George, 2000; Eymur \& Geban, 2011; Okur Akçay, 2014; Sinan, Şardağ, Salifoğlu, Çakır \& Karabacak, 2014; Yıldırım, 2017), income (Aktaş, 2016; Hacıeminoğlu, 2016) and parents' education level (Hacieminoğlu, 2016; Uluçay \& Güven, 2017) affect students' attitude and motivation.

\subsection{Studies on Attitude and Motivation in Biology Education}

When examining the related literature, studies on attitude and motivation appear to focus on general science instead of branches of science, such as physics, chemistry and biology (Saracaloğlu, Serin \& Bozkurt, 2002; Singh, Granville \& Dika, 2002; Aktamış, Ünal \& Ergin, 2008; Cook \& Mulvihill, 2008; Thoe, Thah \& Fook, 2010; Cavas, 2011; Mubeen \& Reid, 2014; Güden \& Timur, 2016). However, the number of studies dealing with both attitude and motivation towards biology is quite limited (Wang, Wu \& Huang, 2007; Y1lmaz, 2012). The findings of the study by Yllmaz (2012), involving 125 biology teacher candidates, showed that candidates' motivation to succeed, academic self-sufficiency and attitude towards the subject were high, while it was noted that the main variables explaining $30 \%$ of field success motivations were self-competence in the field and the attitude towards the field. In the study by Wang Wu \& Hang (2007) on factors affecting high school students' level of learning biology concepts, it was mentioned that attitude and motivation affect learning biology concepts: individuals with high motivation and a positive attitude towards biology have higher levels of learning concepts about biology.

\subsection{Aim of the Present Study}

"Biology provides important knowledge and helps understand nature and causes positive changes in life" (Carvajal-Rodrigez, 2015, as cited in Ozbas, 2016, p. 261). In other words, biology education aims to develop biological literacy in all pupils for making decisions about biological issues (Roberts, 2001). To realize this aim, 
students should be well educated in biology subjects. According to studies, attitude (Atik \& Erkoç, 2015) and motivation (Aluçdibi \& Ekici, 2012a) affect students' biology achievements. Therefore, this study aims to examine science high school students' motivation towards learning biology and attitude towards biology in terms of different variables. In accordance with this aim, this study seeks answers to the following questions:

1) What is the level of students' motivation towards learning biology and attitude towards biology lessons?

2) Is there a significant relationship between students' motivation towards learning biology and attitude towards biology lessons?

3) Is there a meaningful difference between students' gender and their motivation towards learning biology?

4) Is there a meaningful difference between students' gender and their attitude towards biology?

5) Is there a meaningful difference between students' class levels and their motivation towards learning biology?

6) Is there a meaningful difference between students' class levels and their attitude towards biology?

\section{Method}

\subsection{Research Model}

This study was executed using the relational scanning method, which is a descriptive scanning model. The scanning model is a method used in studies whose aim is to describe a situation that started in the past and continues without change. Relational scanning, which takes place in general scanning models, is utilized to determine the coexistence between two or more variables or the level of the coexistence (Cohen, Manison \& Morrison, 2000 and Karasar, 2006, as cited in Ekici \& Hevedanl1, 2010, p. 99).

\subsection{Study Group}

This research's study group consisted of 564 high school students studying at two science high schools in Aksaray, Turkey. The purposive sampling method was utilized in order to determine the sample. In purposive sampling, which is a non-probabilistic sampling method, the sample consists of individuals with an average level of characteristics that are thought to be important to the research. In other words, researchers include people who serve the purpose of the research in purposive sampling (Özen \& Gül, 2007). The reason why science high school students were included in the sample of this study is that these students are far more successful than students from other high schools and have biology lessons throughout their entire schooling. Student admissions to science high schools in Turkey are based on the results of an entrance examination sat after secondary school. Students with the highest scores in this examination, who have an interest in science lessons and want a career related to science (engineering, medical doctorate etc.), are placed in science high schools. Based on the studies revealing affirmative and positive relationships between attitude, motivation and student success, it was thought that more reliable results would be obtained by studying with science high school students. For this reason, sampling was carried out with science high school students. However, biology lessons are mandatorily taught to each class for a period of four years in science high schools, in contrast to other high schools. The distribution of the sample students in terms of their gender and class levels are given in Table 1.

Table 1. Distribution of the study group according to gender and class levels

\begin{tabular}{lllll}
\hline & \multicolumn{2}{l}{ Gender } & \multicolumn{2}{l}{ Class level } \\
\hline & $\mathrm{f}$ & $\%$ & $\mathrm{f}$ & $\%$ \\
\hline Female & 308 & 54.6 & & \\
Male & 256 & 45.4 & & \\
Class 9 & & & 146 & 25.9 \\
Class 10 & & & 150 & 26.6 \\
Class 11 & & & 155 & 27.5 \\
Class 12 & & & 113 & 20.0 \\
Total & 564 & 100 & 564 & 100 \\
\hline
\end{tabular}




\subsection{Data Collection Tools}

\subsubsection{Academic Motivation Scale for Learning Biology}

The Academic Motivation Scale for Learning Biology was utilized in the study to determine students' motivation towards learning biology. The scale, developed by Aydın, Yerdelen, Gürbüzoğlu Yalmancı \& Göksu (2014), consists of 19 items and four subdimensions. The intrinsic motivation subdimension of the scale, which refers to the willingness to learn biology, has six items; the amotivation subdimension, which refers to an unwillingness to learn biology, has five items; the extrinsic motivation-career subdimension, which refers to learning biology for future occupation goals, has four items; and the extrinsic motivation-social subdimension, which refers to learning biology in order to show success to around has four items (Aydın, Yerdelen, Gürbüzoğlu Yalmancı \& Göksu, 2014; Aydın \& Çekim, 2017). The scale has a six-point Likert-type pattern, ranging from strongly agree to strongly disagree (Aydın, Yerdelen, Gürbüzoğlu Yalmancı \& Göksu, 2014). Coding of the scale was done by allocating scores as follows: strongly disagree $=$ one point, mostly disagree $=$ two points, partially disagree $=$ three points, partially agree $=$ four points, mostly agree=five points, strongly agree=six points. Only the items in the amotivation subdimension among the scale items were negative. But, when point scoring, these items were also scored in the same way as the other items on the scale. The lowest average score that could be obtained with the subdimensions of the scale was one, while the highest was six.

Cronbach's alpha values of the scale's subdimensions were stated to be 0.875 for the intrinsic motivation subdimension, 0.841 for the amotivation subdimension, 0.844 for the extrinsic motivation-career subdimension, and 0.736 for the extrinsic motivation-social subdimension (Aydın, Yerdelen, Gürbüzoğlu Yalmancı \& Göksu, 2014). For this study, Cronbach's alpha values were calculated as 0.906 for the intrinsic motivation subdimension, 0.853 for the amotivation subdimension, 0.836 for the extrinsic motivation-career subdimension, and 0.786 for the extrinsic motivation-social subdimension. According to these obtained values, the reliability of the scale was high (McMillan $\&$ Schumacher, 2006).

\subsubsection{Biology Science and Course Attitude Scale}

The Biology Science and Course Attitude Scale, developed by Atik, Kayabaşı, Yağcı \& Ünlü Erkoç (2015), was utilized in order to determine the students' attitude towards biology lessons. The developed scale consists of 23 items, 10 of which are negative, and three subdimensions. The interest subdimension, which is the first subdimension of the scale, aims to determine students' interest in biology lessons and includes nine items; the pleasure subdimension, the second, aims to determine the pleasure that students receive from biology lessons and has eight items; and the anxiety subdimension, the third, aims to determine students' anxiety about biology lessons and has six items (Atik, Kayabaşı, Yağcı \& Ünlü Erkoç, 2015). In this research, scoring was done on a five-point Likert-type scale as follows: strongly disagree $=$ one point, disagree $=$ two points, neutral=three points, agree=four points, strongly agree $=$ five points . In negative items, scoring was done vice versa: strongly disagree=five points, disagree=four points, neutral=three points, agree $=$ two points, strongly agree $=$ one point. The lowest average score that could be obtained from the scale's subdimensions was one, while the highest was five points.

As a result of the reliability analysis, as executed by Atik, Kayabaşı, Yağcı \& Ünlü Erkoç (2015) while developing the scale, it was determined that Cronbach's alpha values of the scale were 0.887 for the interest subdimension, 0.897 for the pleasure subdimension and 0.786 for the anxiety subdimension. For this study, Cronbach's alpha values for the scale's subdimensions were calculated as 0.911 for the interest subdimension, 0.897 for the pleasure subdimension and 0.866 for the anxiety subdimension. The obtained values confirmed that the scale was reliable (McMillan \& Schumacher, 2006).

\subsection{Data Analysis}

Skewness and kurtosis values of the scale's subdimensions, which are used to determine whether or not a study's data show a normal distribution, were calculated. The skewness and kurtosis values obtained in the course of carrying out the analysis, are given in Table 2 . 
Table 2. Skewness and kurtosis values of the subdimensions of the scales used in the study

\begin{tabular}{|c|c|c|c|}
\hline Scale & Subfactors & Skewness value & Kurtosis value \\
\hline \multirow{4}{*}{$\begin{array}{l}\text { Academic Motivation Scale for } \\
\text { Learning Biology }\end{array}$} & Intrinsic motivation & -0.613 & -0.326 \\
\hline & Amotivation & 0.991 & 0.185 \\
\hline & Extrinsic motivation-career & -0.584 & -0.720 \\
\hline & Extrinsic motivation-social & 0.388 & -0.777 \\
\hline \multirow{3}{*}{$\begin{array}{l}\text { Biology Science and Course } \\
\text { Attitude Scale }\end{array}$} & Interest & -0.309 & -0.498 \\
\hline & Pleasure & -0.493 & -0.247 \\
\hline & Anxiety & -0.484 & -0.442 \\
\hline
\end{tabular}

As indicated in Table 2, the skewness and kurtosis values of the subdimensions of the scales were between +1 and -1 . In light of this finding, data were determined to show a normal distribution (Büyüköztürk, 2007). For this reason, in the analysis of the data, parametric tests were utilized. The independent group t-test and the one-way ANOVA test, which are types of parametric tests, were used to determine whether or not students' motivation towards learning biology and their attitude towards biology lessons differed according to their gender and class levels. However, a correlation analysis was carried out to determine the relationship between students' motivation scores for learning biology and attitude scores for biology lessons. Data were interpreted according to arithmetic mean, percentage, frequency and significance levels. The significance level was taken as 0.05 .

\section{Findings}

Mean and standard deviation values belonging to the subdimensions of the Academic Motivation Scale for Learning Biology and the Biology Science and Course Attitude Scale, as well as the Pearson correlation coefficients showing the relationship between subdimensions, are presented in Table 3.

Table 3. Descriptive statistics and Pearson correlation coefficients for the subdimensions of the data collection tools used in the study

\begin{tabular}{|c|c|c|c|c|c|c|c|c|}
\hline \multicolumn{9}{|c|}{ Correlations } \\
\hline Subfactors & Mean & SD & 2 & 3 & 4 & 5 & 6 & 7 \\
\hline 1. Intrinsic motivation & 4.14 & 1.35 & $-.651^{* *}$ & $.470^{* *}$ & $.295^{* *}$ & $.828^{* *}$ & $.735^{* *}$ & $.386^{* *}$ \\
\hline 2. Amotivation & 2.36 & 1.31 & & $-.445^{* *}$ & $-.095^{*}$ & $-.616^{* *}$ & $-.624^{* *}$ & $-.426^{* *}$ \\
\hline 3. Extrinsic motivation-career & 4.25 & 1.45 & & & $.316^{* *}$ & $.440^{* *}$ & $.377^{* *}$ & $.122^{* *}$ \\
\hline 4. Extrinsic motivation-social & 2.84 & 1.33 & & & & $.331^{* *}$ & $.198^{* *}$ & -.029 \\
\hline 5. Interest & 3.30 & .98 & & & & & $.756^{* *}$ & $.354^{* *}$ \\
\hline 6. Pleasure & 3.37 & .98 & & & & & & $.494^{* *}$ \\
\hline 7. Anxiety & 3.48 & .99 & & & & & & \\
\hline
\end{tabular}

** $\mathrm{p}<.001,{ }^{*} \mathrm{p}<.05$

As seen in Table 3, according to the assessment conducted in relation to the Academic Motivation for Learning Biology subdimensions, the arithmetic means of students' scores in intrinsic motivation and extrinsic motivation-career subdimensions were higher than the mean of the six-point Likert-type scale $(X=3.5)$. This finding shows that students show an interest in biology education and a have a desire to learn biology because of their future career goals. On the other hand, the arithmetic mean of the scale's extrinsic motivation-social subdimension was below the scale mean. In other words, science high school students give no importance to the reactions of others (family, friends etc.) about learning biology. The amotivation subdimensions of the scale also have an arithmetic mean value below the scale mean. This low mean shows that students have a high level of willingness and interested in learning biology. As a result of the assessment carried out in relation to the Biology Science and Course Attitude Scale subdimensions among the science high school students, it was determined that the arithmetic means of interest, pleasure and anxiety of the scale were at the medium level (mean is three, according to the five-point Likert-type scale). According to the assessment performed in terms of attitude, the highest arithmetic mean belonged to the anxiety subdimension. This means that the students were anxious about biology. As a result of the assessment in terms of the correlation coefficients, it was determined that the strongest relationships were between the intrinsic 
motivation and interest (.828), and the intrinsic motivation and pleasure (.735) subdimensions. The weakest relationship was between amotivation and extrinsic motivation-social (-.095).

Gender analysis of the mean values, according to the Academic Motivation Scale for Learning Biology, for the science high school students are summarized in Table 4.

Table 4. Gender analysis of the mean values according to the Academic Motivation Scale for Learning Biology

\begin{tabular}{lllllll}
\hline Subfactors & Gender & $\mathrm{N}$ & $X$ & $\mathrm{SS}$ & $\mathrm{t}$ & $\mathrm{p}$ \\
\hline \multirow{2}{*}{ Intrinsic motivation } & Female & 308 & 4.39 & 1.26 & \multirow{2}{*}{4.786} & \multirow{2}{*}{$.000^{*}$} \\
\cline { 2 - 5 } Amotivation & Male & 256 & 3.85 & 1.40 & & \\
\hline \multirow{2}{*}{ Extrinsic motivation-career } & Female & 308 & 2.12 & 1.20 & \multirow{2}{*}{4.654} & \multirow{2}{*}{$.000^{*}$} \\
\cline { 2 - 5 } & Male & 256 & 2.64 & 1.38 & & \\
\hline \multirow{2}{*}{ Extrinsic motivation-social } & Female & 308 & 4.63 & 1.29 & \multirow{2}{*}{0.143} \\
\cline { 2 - 5 } & Male & 256 & 3.79 & 1.49 & \\
\hline 05 & Female & 308 & 2.82 & 1.30 & \multirow{2}{*}{.721} \\
\cline { 2 - 5 } & Male & 256 & 2.86 & 1.37 & & \\
\hline
\end{tabular}

* $\mathrm{p}<.05$

According to Table 4, there is a statistically significant difference between female and male students' arithmetic means in the intrinsic motivation subdimension $(\mathrm{t}=4.786, \mathrm{p}<.05)$, the amotivation subdimension $(\mathrm{t}=4.654, \mathrm{p}<.05)$ and the extrinsic motivation-career subdimension $(\mathrm{t}=7.143, \mathrm{p}<.05)$. This difference favors female students in the intrinsic motivation and extrinsic motivation-career subdimensions, while it favors male students in the amotivation subdimension. In the scale's extrinsic motivation-social subdimension, there is no statistically significant difference between female and male students' arithmetic means $(\mathrm{t}=0.357, \mathrm{p}>.05)$.

The gender analysis results of the science high school students' means, according to the Biology Science and Course Attitude Scale, are summarized in Table 5.

Table 5. Gender analysis of the Biology Science and Course Attitude Scale means

\begin{tabular}{lllllll}
\hline Subfactors & Gender & $\mathrm{N}$ & $X$ & $\mathrm{SS}$ & $\mathrm{t}$ & $\mathrm{p}$ \\
\hline \multirow{2}{*}{ Interest } & Female & 308 & 3.46 & 0.92 & \multirow{2}{*}{4.288} & \multirow{2}{*}{$.000^{*}$} \\
\cline { 2 - 6 } Pleasure & Male & 256 & 3.11 & 1.00 & & \\
\hline \multirow{2}{*}{ Anxiety } & Female & 308 & 3.50 & 0.91 & \multirow{2}{*}{3.671} & \multirow{2}{*}{$.000^{*}$} \\
\cline { 2 - 6 } & Male & 256 & 3.20 & 1.03 & & \\
\hline $\mathrm{p}<.05$ & Female & 308 & 3.52 & 0.96 & \multirow{2}{*}{1.176} & .240 \\
\cline { 2 - 5 } & Male & 256 & 3.42 & 1.02 & & \\
\hline
\end{tabular}

Upon examining the table, it can be seen that there is a statistically significant difference between the arithmetic means of female and male students in the scale's interest subdimension $(t=4.288, p<.05)$ and pleasure subdimension $(\mathrm{t}=3.671, \mathrm{p}<.05)$. According to the obtained values, this difference favors female students. In the scale's anxiety subdimension, there is no statistically significant difference between the arithmetic means of female and male students $(\mathrm{t}=1.176, \mathrm{p}>.05)$.

The analysis of findings, including science high school students' means, on the Academic Motivation Scale for Learning Biology according to class levels, is summarized in Table 6. 
Table 6. Analysis of means on the Academic Motivation Scale for Learning Biology in terms of class levels

\begin{tabular}{lllll}
\hline Subfactors & Class & $\mathrm{N}$ & $X$ & $\mathrm{SS}$ \\
\hline \multirow{3}{*}{ Intrinsic motivation } & Class 9 & 146 & 4.12 & 1.37 \\
& Class 10 & 150 & 4.28 & 1.20 \\
& Class 11 & 155 & 4.12 & 1.43 \\
& Class 12 & 113 & 4.03 & 1.42 \\
\hline \multirow{3}{*}{ Amotivation } & Class 9 & 146 & 2.53 & 1.36 \\
& Class 10 & 150 & 2.26 & 1.18 \\
& Class 11 & 155 & 2.31 & 1.33 \\
Extrinsic motivation-career & Class 12 & 113 & 2.33 & 1.37 \\
& Class 9 & 146 & 4.10 & 1.46 \\
& Class 10 & 150 & 4.52 & 1.30 \\
& Class 11 & 155 & 4.23 & 1.46 \\
Extrinsic motivation-social & Class 12 & 113 & 4.13 & 1.56 \\
& Class 9 & 146 & 3.10 & 1.37 \\
& Class 10 & 150 & 3.00 & 1.32 \\
& Class 11 & 155 & 2.78 & 1.32 \\
& Class 12 & 113 & 2.37 & 1.20
\end{tabular}

The ANOVA results of science high school students' arithmetic means in the subdimensions of the Academic Motivation Scale for Learning Biology are presented in Table 7.

Table 7. ANOVA analysis of the subdimensions of the Academic Motivation Scale for Learning Biology

\begin{tabular}{|c|c|c|c|c|c|c|c|}
\hline Subfactors & $\begin{array}{ll}\text { Source } \\
\text { assumption }\end{array}$ & $\begin{array}{l}\text { Sum } \\
\text { squares }\end{array}$ & SD & $\begin{array}{l}\text { Mean } \\
\text { square }\end{array}$ & $\mathrm{F}$ & $\mathrm{p}$ & $\begin{array}{l}\text { Significant } \\
\text { difference }\end{array}$ \\
\hline \multirow{3}{*}{ Intrinsic motivation } & Between groups & 4.483 & 3 & 1.494 & \multirow{3}{*}{.813} & \multirow{3}{*}{.487} & \multirow{3}{*}{ - } \\
\hline & Within groups & $1,028.718$ & 560 & 1.837 & & & \\
\hline & Total & $1,033.200$ & 563 & & & & \\
\hline \multirow{3}{*}{ Amotivation } & Between groups & 6.364 & 3 & 2.121 & \multirow{3}{*}{1.243} & \multirow{3}{*}{.293} & \multirow{3}{*}{ - } \\
\hline & Within groups & 955.928 & 560 & 1.707 & & & \\
\hline & Total & 962.292 & 563 & & & & \\
\hline \multirow{3}{*}{$\begin{array}{l}\text { Extrinsic } \\
\text { motivation-career }\end{array}$} & Between groups & 15.399 & 3 & 5.133 & \multirow{3}{*}{2.472} & \multirow{3}{*}{.061} & \multirow{3}{*}{-} \\
\hline & Within groups & $1,162.659$ & 560 & 2.076 & & & \\
\hline & Total & $1,178.057$ & 563 & & & & \\
\hline \multirow{3}{*}{$\begin{array}{l}\text { Extrinsic } \\
\text { motivation-social }\end{array}$} & Between groups & 38.731 & 3 & 12.910 & & & \multirow{3}{*}{$\begin{array}{l}9-12 \\
10-12\end{array}$} \\
\hline & Within groups & 959.567 & 560 & 1.714 & 7.534 & $.000^{*}$ & \\
\hline & Total & 998.297 & 563 & & & & \\
\hline
\end{tabular}

The ANOVA results show that there is no statistically significant difference in the arithmetic means of science high school students in the intrinsic motivation $(\mathrm{F}=.813, \mathrm{p}>.05)$, amotivation $(\mathrm{F}=1.243, \mathrm{p}>.05)$ and extrinsic motivation-career $(\mathrm{F}=2.472, \mathrm{p}>.05)$ subdimensions. But, there is a statistically significant difference between students' arithmetic means in the extrinsic motivation-social subdimension in terms of class levels $(\mathrm{F}=7.534, \mathrm{p}<.05)$. The results of the Bonferroni test, which was used to determine the source of the difference, show that 12th grade students' arithmetic means in the extrinsic motivation-social subdimension were statistically lower than for 9th and 10th grade students (Tables 6 and 7). 
The analysis of science high school students' means on the Biology Science and Course Attitude Scale in terms of class levels is summarized in Table 8.

Table 8. Analysis of means on the Biology Science and Course Attitude Scale in terms of class levels

\begin{tabular}{lllll}
\hline Subfactors & Class & N & $X$ & SS \\
\hline \multirow{4}{*}{ Interest } & Class 9 & 146 & 3.27 & 1.00 \\
& Class 10 & 150 & 3.33 & .91 \\
& Class 11 & 155 & 3.31 & 1.02 \\
Pleasure & Class 12 & 113 & 3.29 & .98 \\
& Class 9 & 146 & 3.26 & 1.02 \\
& Class 10 & 150 & 3.52 & .92 \\
& Class 11 & 155 & 3.37 & .96 \\
Anxiety & Class 12 & 113 & 3.30 & 1.00 \\
& Class 9 & 146 & 3.13 & 1.02 \\
& Class 10 & 150 & 3.65 & .88 \\
& Class 11 & 155 & 3.48 & .97 \\
& Class 12 & 113 & 3.69 & 1.00
\end{tabular}

The science high school students' arithmetic mean ANOVA results on the Biology Science and Course Attitude Scale are presented in Table 9.

Table 9. ANOVA analysis of means according to the Biology Science and Course Attitude Scale subdimensions

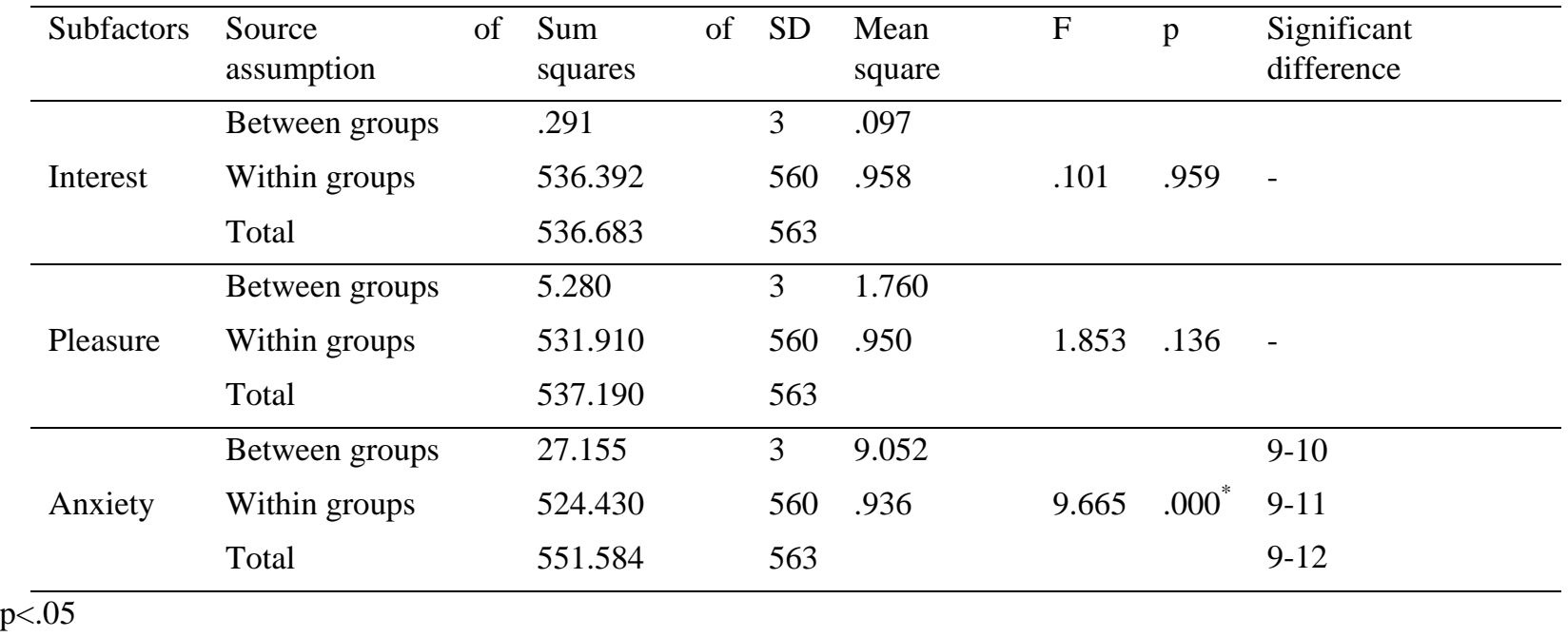

According to the ANOVA results in Table 9, it can be seen that there is no statistically significant difference between science high school students' arithmetic means in the attitude scale's interest $(\mathrm{F}=.101, \mathrm{p}>.05)$ and pleasure $(\mathrm{F}=1.853$, p>.05) subdimensions in terms of class levels. That said, students' arithmetic means in the anxiety subdimension $(\mathrm{F}=9.665, \mathrm{p}<.05)$ differ in a statistically significant way in terms of class levels. As a result of the Bonferroni test findings, it can be stated that ninth grade students have statistically lower arithmetic means in the anxiety subdimension than 10th, 11th and 12th grade students (Tables 8 and 9).

\section{Discussion, Conclusion and Suggestions}

This study aimed to examine science high school students' motivations towards learning biology and their attitude towards biology lessons. The Academic Motivation Scale for Learning Biology, consisting of four subdimensions to determine students' motivation towards learning biology, and the Biology Science and Course Attitude Scale, consisting of three subdimensions, were utilized in the study. Upon examining the findings about students' motivation towards learning biology, it can be determined that students' arithmetic means in the intrinsic motivation and extrinsic motivation-career subdimensions are above the medium level, while those for the amotivation and 
extrinsic motivation-social subdimensions are below the medium level. It can also be stated that the highest arithmetic means are found in the intrinsic motivation and extrinsic motivation-career subdimensions, while the lowest arithmetic means are found in the amotivation and extrinsic motivation-social subdimensions. In light of these findings, students' interest and willingness towards learning biology (intrinsic motivation) and their future occupation (extrinsic motivation-career) can be said to motivate them more towards learning biology. Besides, students' willingness to demonstrate their success to people around them (extrinsic motivation-social) is seen to be less effective in motivating them to learn biology. The amotivation subdimension is the subdimension with the lowest arithmetic mean. The obtained findings are similar to the results reported in previous studies in the literature. In the study by Yerdelen, Aydın, Gürbüzoğlu Yalmancı \& Göksu (2014), which employed the same motivation scale as the one in this study in order to determine the relationship between Anatolian and science high school students' goal orientations and their motivations towards learning biology, it was found that students' arithmetic means in the intrinsic motivation and extrinsic motivation subdimensions were the highest. Besides, it has been stated that amotivation is the subdimension with the lowest arithmetic mean on the scale. Upon evaluating the findings about the motivation towards learning biology in general, it can be stated that they are as expected situation, i.e., that science high schools have students with a high level of success in science and a desire to pursue a science career in Turkey. This situation is thought to explain why science high school students' arithmetic means in the intrinsic motivation and extrinsic motivation-career subdimensions are high. In addition, the reason why science high school students have low arithmetic means in the amotivation subdimension is that the intrinsic motivation subdimension's arithmetic mean among students is high. Moreover, there is a medium-level negative relationship between the amotivation and intrinsic motivation subdimensions (-.651) (Table 3). This means that students with a high internal motivation arithmetic mean have a low amotivation arithmetic mean.

The arithmetic means of science high school students' attitude towards the Biology Science and Course Attitude Scale's subdimensions (interest, pleasure and anxiety) were found to be at the medium level. This finding is consistent with the results of similar studies on students' attitude towards biology lessons (Atik \& Erkoç, 2015). The highest arithmetic mean among the attitude scale subdimensions belongs to the anxiety subdimension. Based on this finding, it can be said that science high school students have a high level of anxiety towards biology lessons. Upon examining the items included in the anxiety subdimension, it can be observed that they all concern the difficulty experienced in a biology lesson (for example, Item 21: Biology is a difficult lesson, and Item 20: Biology is one of the lessons I fear the most). This reiterates the perception that the reason why students have a high level of anxiety is because they find biology lessons difficult (Staeck, 1995; McKee, 2002; Gül \& Yeşilyurt, 2010).

The findings on the correlation between the motivation and attitude subdimension means show that there is a high-level and positive relationship between the intrinsic motivation subdimension and the attitude scale's interest and pleasure subdimensions. Given that internal motivation is about the interest and pleasure related to learning biology, the finding that individuals with an interest in, and experience pleasure while, learning biology have high internal motivation is as expected.

According to the analysis results in terms of gender, there is a statistically significant difference between science high school students' arithmetic means in the intrinsic motivation, amotivation and extrinsic motivation-career subdimensions of the motivation scale and the arithmetic means of the interest and pleasure subdimensions of the attitude scale in terms of students' gender. Statistical findings show that this difference favors females in the intrinsic motivation, extrinsic motivation-career, interest and pleasure subdimensions, but favors males in the amotivation subdimension. These findings are similar to those reported in related studies found in the literature (Ekici \& Hevedanl1, 2010; Aluçdibi \& Ekici, 2012b; Ozbas, 2016). The finding that males have higher arithmetic means in the amotivation subdimension than females shows that male students are unwilling to and uninterested in learning biology. Hence, this result is consistent with the findings reported in Dawson's (2000) study, which was carried out in Australia and showed that female students are more interested in biology lessons than male students. It is thought that the reason why the difference favors females in the motivation and attitude subdimensions is that female students have more interest in biology than male students.

The analysis results for both scales in terms of class levels show that there is a statistically significant difference in the extrinsic motivation-social subdimension on the motivation scale and the anxiety subdimension on the attitude scale according to class level. This observed difference in the extrinsic motivation-social subdimension is determined to exist between 9th, 10th and 12th grade students and favors 9th and 10th grade students. In other words, the willingness of students to demonstrate their success in learning biology to people around them motivates the 12th grade students less than 9th and 10th grade students. This result is supported by the findings reported in Aluçdibi \& Ekici's (2012b) study, which showed that 12th grade students' average extrinsic motivation scores are lower than for 
other class levels. In the anxiety subdimension of the attitude scale, it was found that the arithmetic means of 9th grade students are statistically lower than for the 10th, 11th and 12th grades. According to this result, it can be said that, as the class level goes higher, students' anxiety levels towards learning biology increases. The findings of a related study show that 12th grade students have the highest level of anxiety in relation to biology examinations (Aluçdibi \& Ekici, 2012b; Ongowo \& Hungi, 2014). The reason why this is the case is thought to be linked to upcoming university entrance examinations in the upper school. In our country (Turkey), 12th grade students sit a university entrance examination in the final year of education and learn about what career paths they can take based on the marks they receive. Accordingly, it is thought that the stress and excitement level caused by upcoming examinations increases 12th grade students' anxiety level in biology lessons. In addition, an increasing anxiety level can decrease 12th grade students' desire to demonstrate their success to people around them (i.e., their extrinsic motivation-social arithmetic means) by getting a high score.

In light of the findings obtained at the end of the study, the following suggestions should be taken into consideration:

1. The negative effects of the factors causing amotivation in science high schools towards learning biology should be determined and decreased.

2. Studies should be conducted on increasing levels of students' extrinsic motivation-social subdimension. For example, students who get high scores in biology examinations could be given awards in a ceremony.

3. Studies should be conducted on ensuring students' interest and the pleasure they receive in biology lessons, e.g., by allowing them to carry out biology experiments during lessons.

4. Studies should be conducted on how to decrease students' levels of anxiety about biology lessons.

5. Male students' motivation towards learning biology and their attitude towards biology lessons should be increased.

6. Since 12th grade science high school students must sit a university entrance examination, studies should be conducted on how to reduce their levels of anxiety. For this reason, seminars could be held at schools to reduce examination anxiety.

\section{References}

Afari, E. (2015). Relationship of students' attitudes towards science and academic achievement. In M.S. Khine (Ed.), Attitude Measurements in Science Education: Classic and Contemporary Approaches (pp. 245-262). Charlotte, NC: Information Age Publishing Inc., US.

Akpınar, E., Yıldız, E., Tatar, N., \& Ergin, Ö. (2009). Students' attitudes toward science and technology: An investigation of gender, grade level, and academic achievement. Procedia Social and Behavioral Sciences, 1(1), 2804-2808. https://doi.org/10.1016/j.sbspro.2009.01.498

Aktamış, H., Ünal, G., \& Ergin, Ö. (2008). Öğrencilerin fene yönelik tutumlarına ailelerinin etkisi [The effect of students' family on students' attitude towards science]. Aile ve Toplum [Family and Society], 10(4), 39-48.

Aktaş, N. (2016). Lise ögrencilerinin motivasyon kaynaklarl ve karar verme stratejileri [Motivation resources and decision making strategies of high school students]. Yayımlanmamış Yüksek Lisans Tezi [Unpublished Master Thesis]. Adnan Menderes Üniversitesi Sosyal Bilimler Enstitüsü, Aydın.

Ali, M.S., Iqbal, A., \& Akhtar, M.M.S. (2015). Students' attitude towards science and its relationship with achievement score at intermediate level. Journal of Elementary Education, 25(2), 61-72.

Alkan, A. (2006). Illköğretim öğrencilerinin fen bilgisine karşı tutumları [Primary school students' attitudes toward science courses]. Yayımlanmamış Yüksek Lisans Tezi [Unpublished Master Thesis]. Afyon Kocatepe Üniversitesi Sosyal Bilimler Enstitüsü, Afyon.

Altun, F., \& Yazıcı, H. (2010). Öğrencilerin okul motivasyonunu yordayan bazı değişkenler [Some variables that predict school motivation of students]. International Conference on New Trends in Education and Their Implications Proceedings Book, Retrieved from http://www.iconte.org/FileUpload/ks59689/File/119.pdf

Aluçdibi, F., \& Ekici, G. (2012a). Ortaöğretim öğrencilerinin biyoloji dersi motivasyon düzeylerine biyoloji öğretmenlerinin sınıf yönetimi profillerinin etkisi [The effect of biology teachers' classroom management profiles on the biology course motivation level of the high school students]. Hacettepe Üniversitesi Eğitim Fakültesi Dergisi [Hacettepe University journal of Education], 43, 25-36.

Aluçdibi, F., \& Ekici, G. (2012b). Ortaöğretim öğrencilerinin biyoloji dersi motivasyon düzeylerinin farklı 
değişkenlere göre incelenmesi [The analysis of biology course motivation levels of seconday education students in terms of different variables]. Abant İzzet Baysal Üniversitesi Ĕgitim Fakültesi Dergisi [Abant İzzet Baysal University Journal of Faculty of Education], 12(1), 197-227.

Atik, A.D., Kayabaşı, Y., Yağcı, E., \& Ünlü Erkoç, F. (2015). Ortaöğretim öğrencilerinin biyoloji bilimine ve dersine yönelik tutum ölçeği: Geçerlik ve güvenirlik analizi [The secondary school students biology science and course attitude scale: Analysis of reliability and validity]. Mehmet Akif Ersoy Üniversitesi Eğitim Fakültesi Dergisi [Journal of Mehmet Akif Ersoy University Education Faculty], 36, 1-18.

Atik, A.D., \& Erkoç, F. (2015). Ortaöğretim dokuzuncu sınıf öğrencilerinin biyoloji bilimine ve dersine yönelik tutumlarının çeşitli değişkenler açısından incelenmesi [The investigation of 9th grade students' attitudes towards the science and the course of biology in terms of various variables]. Adlyaman Üniversitesi Eğitim Bilimleri Dergisi [Adlyaman Universty Journal of Educational Sciences], 5(2), 211-244. https://doi.org/10.17984/adyuebd.91698

Aydın, S., Yerdelen, S., Gürbüzoğlu Yalmanc1, S., \& Göksu, V. (2014). Academic motivation scale for learning biology: A scale development study. Education and Science, 39(176), 425-435. https://doi.org/10.15390/EB.2014.3678

Aydın, S., \& Çekim, Z. (2017). Ortaokul öğrencilerinin akademik başarıları ve başarı algılarının fen öğrenmeye yönelik motivasyonlarıyla ilişkisinin incelenmesi [Examining the relationship between the secondary school students' academic achievement and perception of achievement and their motivation to learn science]. Mustafa Kemal Üniversitesi Sosyal Bilimler Enstitüsü Dergisi [Mustafa Kemal University Journal of Social Sciences Institute], 14(39), 458-470.

Bahar, M., Johnstone, A.H., \& Hansell, M.H. (1999). Revisiting learning difficulties in biology. Journal of Biological Education, 33(2), 84-86. https://doi.org/10.1080/00219266.1999.9655648

Bryan, R.R., Glynn, S.M., \& Kittleson, J.M. (2011). Motivation, achievement, and advanced placement intent of high school students learning science. Science Education, 95(6), 1049-1065. https://doi.org/10.1002/sce.20462

Büyüköztürk, Ş. (2007). Sosyal bilimler için veri analizi el kitabı istatistik, araştırma deseni, SPSS uygulamaları ve yorum. (7. Baskı), Ankara: Pegem A Yayıncılık.

Cavas, P. (2011). Factors affecting the motivation of Turkish primary students for science learning. Science Education International, 22(1), 31-42.

Chow, S.J., \& Yong, B.C.S. (2013). Secondary school students' motivation and achievement in combined science. US-China Education Review B, 3(4), 213-228.

Cook, M., \& Mulvihill, T.M. (2008). Examining US college students' attitudes towards science: Learning from non-science majors. Educational Research and Review, 3(1), 38-47.

Craker, D.E. (2006). Attitudes toward science of students enrolled in introductory level science courses at UW-La crosse. UW-L Journal of Undergraduate Research, IX, 1-6.

Çimer, A. (2012). What makes biology learning difficult and effective: Students' views. Educational Research and Reviews, 7(3), 61-71.

Dawson, C. (2000). Upper primary boys' and girls' interests in science: Have they changed since 1980?, International Journal of Science Education, 22(6), 557-570. https://doi.org/10.1080/095006900289660

Ekici, G., \& Hevedanlı, M. (2010). Lise öğrencilerinin biyoloji dersine yönelik tutumlarının farklı değişkenler açısından incelenmesi [Examination of high school students' attitudes towards biology in terms of different variables]. Türk Fen Ĕgitimi Dergisi [Journal of Turkish Science Education], 7(4), 97-109.

Elmas, Z.T. (2013). İlköğretim öğrencilerinin ve ögretmenlerinin fen ve teknoloji dersindeki ögrencinin başarısını, tutumuпи ve motivasyonunu etkileyen ögretmen nitelikleri ile ilgili algilarl [The effects of teachers' characteristics on elementary school students' and teachers' perceptions about students' achievement, motivation and attitudes in science and technology course]. Yayımlanmamış Yüksek Lisans Tezi [Unpublished Master Thesis]. Mehmet Akif Ersoy Üniversitesi Eğitim Bilimleri Enstitüsü, Burdur.

Ergün, M. (2003). Sinıfta motivasyon. In E. Karip (Ed.), Sinıf Yönetimi (pp. 115-129). (Üçüncü Baskı). Ankara: Pegem A Yayıncilık.

Eymur, G., \& Geban, Ö. (2011). An Investigation of the relationship between motivation and academic achievement 
of pre-service chemistry teachers. Education and Science, 36(161), 246-255.

Fidan Dişikitli, A. (2011). İlköğretim 7. ve 8. sinı ögrencilerinin fen ve teknoloji dersine yönelik tutumlart ile fen ve teknoloji dersi başarllarl arasındaki ilişki [The relationship between the attitudes of the primary 7 th and 8 th grade students towards the course of science and technology and their science and technology success]. Yayımlanmamış Yüksek Lisans Tezi [Unpublished Master Thesis]. Selçuk Üniversitesi Eğitim Bilimleri Enstitüsü, Konya.

George, R. (2000). Measuring change in students' attitudes toward science over time: An application of latent variable growth modeling. Journal of Science Education and Technology, 9(3), 213-225.

Gömleksiz, M.N., \& Serhatlığlu, B. (2013). Öğretmen adaylarının akademik motivasyon düzeylerine ilişkin görüşleri [Prospective teachers' perceptions of academic motivation levels]. Türkiye Sosyal Araşttrmalar Dergisi [Journal of Turkish Social Research], 17(3), 99-128.

Güden, C., \& Timur, B. (2016). Ortaokul öğrencilerinin fen bilimlerine yönelik tutumlarının bazı değişkenlere göre incelenmesi (Çanakkale örneği) [Examining secondary school students' attitudes towards science based on various variables (Çanakkale sample)]. International Journal of Active Learning, 1(1), 49-72.

Gül, Ş., \& Yeşilyurt, S. (2010). Ortaöğretim öğrencilerinin biyoloji ve biyoloji dersine yönelik tutumları (Pilot uygulama) [Secondary education students' attitudes towards biology and biology lesson (Pilot study)]. Mehmet Akif Ersoy Üniversitesi Eğitim Fakültesi Dergisi [Journal of Mehmet Akif University Education Faculty], 10(20), 28-47.

Hacieminoglu, E. (2016). Elementary school students' attitude toward science and related variables. International Journal of Environmental \& Science Education, 11(2), 35-52. https://doi.org/10.12973/ijese.2016.288a

Hegarty, N. (2010). Application of the academic motivation scale to graduate school students. The Journal of Human Resource and Adult Learning, 6(2), 48-55.

Jebson, S.R., \& Hena, A.Z. (2015). Students' attitude towards science subjects in senior secondary schools in Adamawa State, Nigeria. IMPACT: International Journal of Research in Applied, Natural and Social Sciences, 3(3), 117-124.

Kardaş, M.N., \& Uca, N. (2016). Aktif öğrenme yönteminin kullanıldığı çalışmaların öğrenci başarısı, tutumu ve görüşleri açısından incelenmesi: Bir meta-analiz çalışması [The relationship between active learning method the views of students on achievement; attitude and applications: A study of meta-analysis]. Uluslar arası Türk Eğitim Bilimleri Dergisi [International Journal of Turkish Education Sciences], 4(7), 118-130.

Kaya, H., \& Böyük, U. (2011). İlköğretim II. kademe öğrencilerinin fen ve teknoloji dersine ve fen deneylerine karş1 tutumlar1 [Attitudes towards science and technology cours and science experiments of the elementary school's 2nd grade students]. TÜBAV Bilim Dergisi [TUBAV Science Journal], 4(2), 120-130.

Korur, F., \& Eryılmaz, A. (2002). Öğretmen niteliklerinin lise seviyesindeki öğrencilerin fizik başarı, tutum ve motivasyonuna etkileri [The effects of teacher characteristics on high school students' physics achievement, attitude and motivation]. V. Ulusal Fen Bilimleri ve Matematik Eğitimi Kongresi Bildiriler Kitabı [5th National Science and Mathematic Education Congress Proceedings Book], Retrieved from http://old.fedu.metu.edu.tr/ufbmek-5/b_kitabi/PDF/Fizik/Bildiri/t125.pdf

Korur, F. (2008). Multiple case study on how physics teachers' characteristics affect studnts' motivation in physics. Unpublished Doctoral Dissertion. Middle East Technical University The Graduate School of Natural and Applied Sciences, Ankara.

Kumari, S.N., \& Saraladevi, K. (2014). Gender differences in attitude towards science teaching and learning styles among adolescents. International Journal of Science and Research, 3(10), 50-58.

Magwilang, E.B. (2016). Teaching chemistry in context: Its effects on students' motivation, attitudes and achievement in chemistry. International Journal of Learning, Teaching and Educational Research, 15(4), 60-68.

Martin, M.O., Mullis, I.V.S., Foy, P., \& Stanco, G.M. (2012). TIMMS 2011 international results in science. Retrieved from https://timssandpirls.bc.edu/timss2011/downloads/T11_IR_Science_FullBook.pdf

McKee, G. (2002). Why is biological science difficult for first-year nursing students?. Nurse Education Today, 22, 251-257. https://doi.org/10.1054/nedt.2001.0700 
McMillan, J. H., \& Schumacher, S. (2006). Research in education: Evidence-based inquiry. (Sixth Edition). London: Pearson

Moralar, A. (2012). Fen eğitiminde probleme dayalı öğrenme yaklaşımının akademik başarı, tutum ve motivasyona etkisi [The effect of problem-based learning approach on academic success, attitude and motivation in science education]. Yayımlanmamış Yüksek Lisans Tezi [Unpublished Master Thesis]. Trakya Üniversitesi Fen Bilimleri Enstitüsü, Edirne.

Mubeen, S., \& Reid, N. (2014). The measurement of motivation with science students. European journal of Educational Research, 3(3), 129-144.

Nasr, A.R., \& Soltani K.A. (2011). Attitude towards biology and its effects on student's achievement. International Journal of Biology, 3(4), 100-104. https://doi.org/10.5539/ijb.v3n4p100

Okur Akçay, N. (2014). Okul öncesi öğretmeni adaylarının fene yönelik tutumlarının çeşitli değişkenlere göre incelenmesi [The investigation of preschool teacher candidates' attitudes towards science teaching according to several variables]. The Journal of Academic Social Science Studies, 30, 325-336. https://doi.org/10.9761/JASSS2580

Ongowo, R.O., \& Hungi, S.K. (2014). Motivational beliefs and self-regulation in biology learning: Influence of ethnicity, gender and grade level in Kenya. Creative Education, 5, 218-227. https://doi.org/10.4236/ce.2014.54031

Ozbas, S. (2016). High school students' intrinsic and extrinsic regulation in learning biology. International Journal of Educational Sciences, 15(1,2), 261-268.

Özen, Y., \& Gül, A. (2007). Sosyal ve eğitim bilimleri araştırmalarında evren-örneklem sorunu [Population-sampling issue on social and educational research studies]. Kazım Karabekir Eğitim Fakültesi Dergisi [Journal of Kazim Karabekir Education Faculty], 15, 394-422.

Papanastasiou, C. (2002). School, teaching and family influence on student attitudes toward sceince: Based on TIMMS data for Cyprus. Studies in Educational Evaluation, 28(1), 71-86.

Prokop, P., Tuncer, G., \& Chudá, J. (2007). Slovakian students' attitudes toward biology. Eurasia Journal of Mathematics, Science \& Technology Education, 3(4), 287-295.

Roberts, R. (2001). Procedural understanding in biology: the 'thinking behind the doing'. Journal of Biological Education, 35(3), 113-117. https://doi.org/10.1080/00219266.2001.9655758

Ryan, R.M., \& Deci, E.L. (2000). Intrinsic and extrinsic motivations: Classic definitions and new directions. Contemporary Educational Psychology, 25, 54-67. https://doi.org/10.1006/ceps.1999.1020

Sadi, Ö., Uyar, M., \& Yalçın, H. (2014). Lise öğrencilerinin biyoloji dersi başarılarında, cinsiyet, sınıf düzeyi ve aile yapısının rolü [The role of gender, grade level and family environment in high school students' biology achievement]. Ĕgitim ve Öğretim Araştırmaları Dergisi [Journal of Research in Education and Teaching], 3(2), 138-151.

Saracaloğlu, A.S., Serin, O., \& Bozkurt, N. (2002). Öğretmen adaylarının fen bilimlerine yönelik tutumları ile başarıları arasındaki ilişki [The relationship between attitudes towards science and achievement of prospective teachers]. Ege Eğitim Dergisi [Aegean Education Journal], 1(2), 76-85.

Sinan, O., Şardağ, M., Salifoğlu, A., Çakır, C., \& Karabacak, Ü. (2014). İlköğretim öğrencilerinin fen tutumları ve özyeterliliklerinin incelenmesi [Investigation of primary school students' science attitudes and self-efficacy]. Necatibey Eğitim Fakültesi Elektronik Fen ve Matematik Ĕgitimi Dergisi (EFMED) [Necatibey Faculty of Education Electronic Journal of Science and Mathematics Education], 8(1), 68-100. https://doi.org/10.12973/nefmed.2014.8.1.a4

Singh, K., Granville, M., \& Dika, S. (2002). Mathematics and science achievement: Effects of motivation, interest, and academic engagement. The Journal of Educational Research, 95(6), 323-332. https://doi.org/10.1080/00220670209596607

Spittle, M., Jackson, K., \& Casey, M. (2009). Applying self-determination theory to understand the motivation for becoming a physical education teacher. Teaching and Teacher Education, 25, 190-197. https://doi.org/10.1016/j.tate.2008.07.005

Staeck, L. (1995). Perspectives for biological education-challenge for biology instruction at the end of the 20th 
century. Hacettepe Üniversitesi Eğitim Fakültesi Dergisi [Hacettepe University Journal of Education], 11, 29-35.

Tekkaya, C., Özkan, Ö., \& Sungur, S. (2001). Lise öğrencilerinin zor olarak algıladıkları biyoloji kavramları [Biology concepts perceived as difficult by Turkish high school students]. Hacettepe Üniversitesi Ĕgitim Fakültesi Dergisi [Hacettepe University Journal of Education], 21, 145-150.

Temelli, A., \& Kurt, M. (2010). Eğitim fakültesi ve fen fakültesi biyoloji öğrencilerinin ders çalışma alışkanlıklarının farklı değişkenler açısından incelenmesi [The analysis of biology students' studying habits in science and education faculties in terms of different variables]. Kuramsal Eğitim Bilim [Journal of Theoretical Educational Science], 3(2), 27-36.

Thoe, N.K., Thah, S.S., \& Fook, F.S. (2010). Development of a questionnaire to evaluate students' perceived

motivation towards science learning incorporating ICT tool. Malaysian Journal of Educational Technology, 10(1), 39-55.

Tuan, H.L., Chin, C.C., \& Shieh, S.H. (2005). The development of a quastionnaire to measure students' motivation towards science learning. International Journal of Science Education, 27(6), 639-654. https://doi.org/10.1080/0950069042000323737

Uluçay, B., \& Güven, S. (2017). Ortaokul öğrencilerinin matematik dersi motivasyon düzeyleri ile algılanan öğretmen yakınlığı arasındaki ilişki [The relationship between mathematical motivation and perceived teacher closeness of secondary school students]. Ĕgitim ve Ögrretim Araştırmaları Dergisi [Journal of Research in Education and Teaching], 6(3), 252-266.

Uyulgan, M.A., \& Akkuzu, N. (2014). Öğretmen adaylarının akademik içsel motivasyonlarına bir bakış [An overwiev of student teachers' academic intrinsic motivation]. Kuram ve Uygulamada Eğitim Bilimleri [Educational Sciences: Theory \& Practice], 14(1), 7-32. https://doi.org/10.12738/estp.2014.1.2013

Uzezi, J.G., \& Jonah, K.J. (2017). Effectiveness of brain-based learning strategy on students' academic achievement, attitude, motivation and knowledge retention in electrochemistry. Journal of Education, Society and Behavioural Science, 21(3), 1-13. https://doi.org/10.9734/JESBS/2017/34266

Wang, M.N.M., Wu, K.C., \& Huang, T.C.I. (2007). A study on the factors affecting biological concept learning of junior high school students. International Journal of Science Education, 29(4), 453-464. https://doi.org/10.1080/09500690601073152

Watters, J.J., \& Ginns, I.S. (2000). Developing motivation to teach elementary science: Effect of collaborative and authentic learning practices in preservice education. Journal of Science Teacher Education, 11(4), 301-321.

Yenice, N., Saydam, G., \& Telli, S. (2012). İlköğretim öğrencilerinin fen öğrenmeye yönelik motivasyonlarını etkileyen faktörlerin belirlenmesi [Determining factors effecting on primary school students' motivation towards science learning]. Ahi Evran Üniversitesi Kirşehir Eğitim Fakültesi Dergisi [Ahi Evran University Journal of Kırşehir Education Faculty], 13(2), 231-247.

Yerdelen, S., Aydın, S., Gürbüzoğlu Yalmancı, S., \& Göksu, V. (2014). Relationship between high school students' achievement goal orientation and academic motivation for learning biology: A path analysis. Education and Science, 39(176), 437-446. https://doi.org/10.15390/EB.2014.3679

Yeşilyurt, S., \& Gül, Ş. (2009). Biyoloji tutum ölçeği [Biology attitude scale]. Erzincan Eğitim Fakültesi Dergisi [Erzincan University Journal of Education Faculty], 11(2), 239-258.

Yıldırım, T. (2017). An examination of high school social science students' levels motivation towards learning geography. International Education Studies, 10(7), 1-9. https://doi.org/10.5539/ies.v10n7p1

Yılmaz, M. (2012). Biyoloji öğretmeni adaylarının biyolojide başarılı olma motivasyonunu yordayan değişkenlerin incelenmesi [Investigation of variables that predict motivation of biology teacher candidates to succeed in biology]. X. Ulusal Fen Bilimleri ve Matematik Eğitimi Kongresi Bildiriler Kitabl [10th National Science and Mathematic Education Congress Proceedings Book], Retrieved from http://kongre.nigde.edu.tr/xufbmek/dosyalar/tam_metin/pdf/2299-28_05_2012-23_13_39.pdf 